\title{
GAMBARAN TINGKAT PENGETAHUAN MASYARAKAT TENTANG EPILEPSI DI KELURAHAN MAHENA KECAMATAN TAHUNA KABUPATEN SANGIHE
}

\author{
${ }^{1}$ Dimas Prasetyo Gunawan \\ ${ }^{2}$ Karema Winifred \\ ${ }^{2}$ Junita Maja P. S \\ ${ }^{1}$ Kandidat skripsi Fakultas Kedokteran Universitas Sam Ratulangi Manado
${ }^{2}$ Bagian/SMF Neurologi Fakultas Kedokteran Universitas Sam Ratulangi Manado
Email: dimasprasetyo10_020@yahoo.com
}

Abstract: Epilepsy is one of the oldest disease in the world and ranked two on neurology diseases after stroke. Approximately 50 million people worldwide suffer from epilepsy. Although epilepsy is widely known, low level knowledge about this diseases leads to people with epilepsy being stigmatized and discriminated. This study aimed to examine the level of knowledge about epilepsy in Mahena village, Tahuna district, Sangihe regency. This was a descriptive study using 93 people of Mahena village communities. Questionnaire consisting of 12 questions were filled by the respondents. The results showed that of the 93 respondents, $60.2 \%$ were females, $28 \%$ were aged 16-24 years, and $46.2 \%$ were high school/equivalent educated. There were $32,3 \%$ worked as civil servant. Majority of respondents have enough knowledge about epilepsy (51.6\%), 40 persons (43\%) of respondents have a poor level of knowledge about epilepsy and only 5 (5.4\%) who have a good level of knowledge about epilepsy. Conclusion: Most people of Mahena, Tahuna had enough knowledge about epilepsy, however, there were still many who had low knowledge about epilepsy.

Keywords: epilepsy, knowledge level

\begin{abstract}
Abstrak: Epilepsi adalah salah satu penyakit tertua di dunia dan menempati urutan kedua dari penyakit saraf setelah stroke. Penyakit ini diderita oleh kurang lebih 50 juta orang di seluruh dunia. Walaupun telah dikenal secara luas, rendahnya tingkat pengetahuan masyarakat tentang penyakit ini dapat menimbulkan stigma yang mengakibatkan terjadinya diskriminasi terhadap penderita epilepsi. Penelitian ini bewrtujuan untuk mengetahui gambaran tingkat pengetahuan masyarakat mengenai epilepsi. Penelitian merupakan suatu studi deskriptif terhadap 93 orang warga masyarakat kelurahan Mahena. Kuesioner yang digunakan terdiri dari 12 pertanyaan yang diisi sendiri oleh warga masyarakat. Hasil penelitian menunjukkan dari 93 orang responden, 60,2\% berjenis kelamin perempuan, 28\% responden berusia 16-24 tahun, dan 46,2\% berpendidikan terakhir SMA/SMK/sederajat. Sebanyak 32,3\% bekerja sebagai PNS/pegawai kantoran. Sebagian besar responden (51,6\%) memiliki pengetahuan cukup mengenai epilepsi, 40 orang (43\%) responden memiliki tingkat pengetahuan buruk mengenai epilepsy, dan hanya 5 orang $(5,4 \%)$ memiliki tingkat pengetahuan baik mengenai epilepsi. Simpulan: Walaupun sebagian besar masyarakat kelurahan Mahena, Tahuna sudah memiliki tingkat pengetahuan cukup tentang epilepsi, masih banyak juga yang memiliki tingkat pengetahuan kurang tentang epilepsi.
\end{abstract}

Kata kunci: epilepsi, tingkat pengetahuan 
Epilepsi adalah salah satu penyakit tertua di dunia dan menempati urutan kedua dari penyakit saraf setelah gangguan peredaran otak. ${ }^{1}$ Penyakit ini diderita oleh kurang lebih 50 juta orang di seluruh dunia. Epilepsi bertanggung jawab terhadap $1 \%$ dari beban penyakit global, dimana $80 \%$ beban tersebut berada di negara berkembang. Pada negara berkembang di beberapa area $80-90 \%$ kasus tidak menerima pengobatan sama sekali. ${ }^{2}$

Secara keseluruhan insiden epilepsi pada negara maju berkisar antara 40-70 kasus per 100.000 orang per tahun. Di negara berkembang, insiden berkisar antara 100-190 kasus per 100.000 orang per tahun. Prevalensi dari epilepsi bervariasi antara 510 kasus per 1.000 orang. $^{3}$

Di Indonesia belum ada data yang pasti mengenai penderita epilepsi, tetapi diperkirakan ada 1-2 juta penderita epilepsi. Prevalensi epilepsi di Indonesia adalah 5-10 kasus per 1.000 orang dan insiden 50 kasus per 100.000 orang per tahun. ${ }^{4}$

Epilepsi telah dikenal sejak lama dan secara luas dalam masyarakat Indonesia. Hal ini terbukti dengan adanya istilah-istilah bahasa daerah untuk penyakit ini, seperti sawan, ayan, sekalor, dan celengan. ${ }^{1}$ Walaupun telah dikenal secara luas, rendahnya tingkat pengetahuan masyarakat tentang penyakit ini mengakibatkan timbulnya stigma yang mengakibatkan terjadinya diskriminasi terhadap penderita epilepsi. Penderita epilepsi sering digolongkan dalam penyakit gila, kutukan, atau turunan sehingga penderita tidak diobati atau bahkan disembunyikan oleh keluarganya. Akibatnya banyak penderita epilepsi yang tak terdiagnosis dan tidak mendapatkan pengobatan yang tepat sehingga menimbulkan dampak klinik dan psikososial yang merugikan baik bagi penderita maupun keluarganya. ${ }^{5}$

Penelitian terakhir menemukan bahwa penderita epilepsi lebih rentan menderita kecemasan, depresi dan rendah diri. Beberapa masalah lain yang dihadapi oleh penderita epilepsi dewasa adalah pengganguran, kecenderungan tidak menikah dan isolasi sosial. ${ }^{6}$

\section{METODE PENELITIAN}

Penelitian ini bersifat deskriptif dan dilaksanakan dengan metode survei. Penelitian ini dilakukan pada bulan November-Desember 2013 di Kelurahan Mahena, Kecamatan Tahuna, Kabupaten Sangihe dengan jumlah sampel 93 orang. Kuesioner yang digunakan adalah knowledge, attitudes and practice toward epilepsy UC Berkeley yang diterjemahkan ke dalam bahasa Indonesia, yang terdiri dari 12 pertanyaan yang meliputi kesadaran mengenai epilepsi, etiologi, manifestasi klinik, penanganan serangan dan pengobatan epilepsi.

\section{HASIL PENELITIAN}

Pada penelitian ini didapatkan karakteristik responden, meliputi jenis kelamin, umur, pekerjaan dan tingkat pendidikan. Untuk memeperoleh gambaran distribusi menurut karakteristik responden dapat dilihat pada tabel berikut:

Tabel 1. Distribusi responden berdasarkan jenis kelamin

\begin{tabular}{ccc}
\hline Jenis kelamin & $\mathrm{n}$ & $\%$ \\
\hline Laki-laki & 37 & 39,8 \\
Perempuan & 56 & 60,2 \\
Jumlah & 93 & 100 \\
\hline
\end{tabular}

Tabel diatas menunjukkan responden dengan jenis kelamin perempuan lebih banyak dari responden dengan jenis kelamin laki-laki. 
Tabel 2. Distribusi responden berdasarkan umur

\begin{tabular}{ccc}
\hline Umur & $\mathrm{n}$ & $\%$ \\
\hline $16-24$ & 26 & 28,0 \\
$25-34$ & 16 & 17,2 \\
$35-44$ & 24 & 25,8 \\
$45-54$ & 23 & 24,7 \\
$55-64$ & 4 & 4,3 \\
Jumlah & 93 & 100 \\
\hline
\end{tabular}

Tabel 2 menunjukkan sebagian besar responden berada dalam kelompok umur 1624 tahun yaitu sebanyak 26 orang dan paling sedikit adalah kelompok umur 55-64 yaitu sebanyak 4 orang.

Tabel 3. Distribusi responden berdasarkan pekerjaan

\begin{tabular}{ccc}
\hline Pekerjaan & $\mathrm{n}$ & $\%$ \\
\hline Pelajar & 16 & 17,2 \\
Buruh & 7 & 7,5 \\
Petani & 5 & 5,4 \\
PNS/pegawai kantoran & 30 & 32,3 \\
Wiraswasta/pedagang & 6 & 6,5 \\
Pengangguran & 3 & 3,2 \\
Lainnya & 26 & 28,0 \\
Jumlah & 93 & 100 \\
\hline
\end{tabular}

Dari tabel diatas dapat dilihat bahwa sebagian responden bekerja sebagai PNS/pegawai kantoran yaitu sebanyak 30 orang sedangkan paling sedikit adalah pengangguran yaitu sebanyak 3 orang.

Tabel 4. Distribusi responden berdasarkan tingkat pendidikan

\begin{tabular}{ccc}
\hline Tingkat pendidikan & $\mathrm{n}$ & $\%$ \\
\hline Tidak sekolah & 0 & 0 \\
SD & 9 & 9,7 \\
SMP/sederajat & 14 & 15,1 \\
SMA/SMK/sederajat & 43 & 46,2 \\
Perguruan tinggi & 27 & 29 \\
Jumlah & 93 & 100 \\
\hline
\end{tabular}

Dari tabel 4 dapat dilihat bahwa sebagian besar responden mencapai tingkat pendidikan terakhir SMA/SMK/sederajat yaitu sebanyak 14 orang.

Tabel 5. Tingkat pengetahuan masyarakat mengenai epilepsi

\begin{tabular}{ccc}
\hline Pekerjaan & $\mathrm{n}$ & $\%$ \\
\hline Baik & 5 & 5,4 \\
Cukup & 48 & 51,6 \\
Kurang & 40 & 43,0 \\
Jumlah & 93 & 100 \\
\hline
\end{tabular}

Dari tabel diatas dapat dilihat bahwa sebagian besar responden memliliki pengetahuan yang cukup mengenai epilepsi, hanya 5 orang yang memiliki tingkat pengetahuan yang baik mengenai epilepsi dan 40 orang responden memiliki tingkat pengetahuan yang buruk mengenai epilepsi.

Dari 93 orang responden didapatkan 84 orang $(90,3 \%)$ pernah mendengar atau membaca tentang epilepsi, 66 orang (71\%) responden menjawab mengenal seseorang yang menyandang epilepsi, 69 orang (74,2\%) responden memilih pernah melihat kejadian serangan epilepsi secara langsung maupun di televisi, 30 orang responden (32,3\%) menganggap epilepsi sebagai penyakit jiwa, 51 orang responden (54,8\%) menganggap kecerdasan penyandang 
epilepsi lebih rendah dari orang normal, 37 orang (39,8\%) responden berpendapat bahwa penderita epilepsi dapat membahayakan orang lain dan 40 orang (43\%) responden menganggap anak yang menyandang epilepsi perlu disekolahkan di tempat pendidikan khusus.

Tabel 6. Distribusi frekuensi pengetahuan responden mengenai etiologi dan manifestasi klinik epilepsi

\begin{tabular}{lll}
\hline \multicolumn{1}{c}{ Pertanyaan } & $\begin{array}{c}\text { Jumlah } \\
\text { n=93 }\end{array}$ & Persen \\
\hline Etiologi & 15 & 15,5 \\
$\quad$ Infeksi & 23 & 23,7 \\
Penyakit otak & 26 & 26,8 \\
Keturunan & 22 & 22,7 \\
Cacat dari lahir & & \\
(kongenital) & 64 & 66 \\
Gangguan pada saraf & 2 & 2,1 \\
Penyakit darah & 3 & 3,1 \\
Kutukan/ilmu hitam & & \\
Terlalu banyak & 3 & 3,1 \\
menggunakan alat & & \\
elektronik & 3 & 3,1 \\
Hukuman dari Tuhan & 14 & 15,4 \\
Tidak tahu & & \\
Manifestasi klinik & & 85,6 \\
Kejang & 83 & 53,6 \\
Gemetar & 52 & 55,7 \\
Hilang kesadaran & 54 & 14,4 \\
Perubahan sikap & 14 & 23,7 \\
Hilang ingatan & 23 & 3,1 \\
Tidak tahu & 3 &
\end{tabular}

Dari tabel diatas dapat dilihat bahwa responden paling banyak memilih gangguan pada saraf (66\%) sebagai etiologi epilepsi dan paling sedikit memilih penyakit darah $(2,1 \%)$ serta 14 orang $(15,4 \%)$ memilih tidak tahu.

Dari tabel diatas didapatkan 83 orang (85,6\%) memilih kejang sebagai karakteristik epilepsi, 52 orang (53,6\%) memilih gemetar, 54 orang $(55,7 \%)$ memilih hilang kesadaran, 14 orang (14,4\%) memilih perubahan sikap, 23 orang (23,7\%) memilih hilang ingatan dan 3 (3,1\%) orang memilih tidak tahu.

Penelitian menunjukkan bahwa 60 orang (66\%) responden beranggapan bahwa saat terjadi serangan, benda keras harus dimasukkan ke mulut penderita, dimana 21 orang (35\%) memilih buku sebagai sumber informasi tersebut, 9 orang (15\%) memilih televisi, $41 \quad(68,3 \%)$ orang memilih perkataan orang lain dan 10 orang (16,7\%) memilih lainnya sedangkan 33 orang (34\%) memilih tidak perlu memasukkan benda keras ke mulut penderita saat terjadi serangan.

Dari hasil penelitian didapatkan bahwa 85 orang $(91,4 \%)$ percaya bahwa epilepsi dapat disembuhkan dan 59 orang $(63,4 \%)$ responden menganggap obat adalah satusatunya cara mengendalikan epilepsi.

\section{BAHASAN}

Berdasarkan penelitian yang sudah dilakukan, dari 93 responden masyarakat Kelurahan Mahena, Kecamatan Tahuna hanya didapatkan 5,4\% responden memiliki tingkat pengetahuan yang baik, 51,6\% responden memiliki tingkat pengetahuan yang cukup dan $43 \%$ responden memiliki tingkat pengetahuan yang kurang mengenai epilepsi. Hal ini menunjukkan sebagian besar masyarakat Kelurahan Mahena memiliki pengetahuan yang cukup tentang epilepsi.

Pada penelitian ini didapatkan 90,3\% responden pernah mendengar atau membaca tentang epilepsi, 71\% responden mengenal seseorang yang menyandang epilepsi dan $74,2 \%$ responden pernah melihat kejadian serangan epilepsi secara langsung. Hasil ini sebanding dengan data yang didapat oleh Johannes H.S di Medan tahun 2010 yaitu 90,5\% responden pernah mendengar mengenai epilepsi tetapi lebih tinggi daripada hasil yang didapat pada penelitian yang dilakukan Kenny C dkk di Amerika 
Serikat tahun 2010, yaitu hanya 40\% responden mengenal seseorang yang menyandang epilepsi dan 55\% pernah melihat serangan epilepsi secara langsung. ${ }^{8-9}$ Hal ini menunjukkan bahwa penyakit ini dikenal secara luas di masyarakat.

Sebanyak

$32,3 \%$

responden

menganggap epilepsi sebagai penyakit jiwa, hasil ini sebanding dengan data yang didapat oleh Ab Fatah Ab Rahman di Malaysia tahun 2005, yaitu 39,7\% menganggap epilepsi sebagai penyakit jiwa. ${ }^{10}$ Sebanyak $54,8 \%$ responden menganggap kecerdasan penyandang epilepsi lebih rendah dari orang normal, hasil ini lebih tinggi dari data yang didapat Kenny C dkk di Amerika Serikat tahun 2010 yaitu $25 \%$ responden menganggap kecerdasan penyandang epilepsi lebih rendah dari orang normal. ${ }^{9}$ $39,8 \%$ responden berpendapat bahwa penderita epilepsi dapat membahayakan orang lain, hasil ini lebih tinggi dari data yang didapat Kenny C dkk di Amerika Serikat tahun 2010 yaitu 18\% responden berpendapat bahwa penderita epilepsi membahayakan orang lain. ${ }^{9} 43 \%$ responden menganggap anak yang menyandang epilepsi perlu disekolahkan di tempat pendidikan khusus, hasil ini sebanding dengan hasil penelitian oleh Abdelmoneim A dan Fatma S di Kuwait tahun 2008 yang menemukan 44,1\% responden menganggap anak yang menyandang epilepsi perlu disekolahkan di tempat pendidikan khusus. ${ }^{11}$ Dapat dilihat bahwa masih banyak masyarakat yang memiliki pemahaman mengenai epilepsi.

Tabel 6 menunjukkan pilihan masyarakat mengenai etiologi epilepsi, adalah gangguan pada saraf (66\%), keturunan (26,8\%), penyakit otak (23,7\%), cacat dari lahir (22,7\%), infeksi (15,5\%), penyakit darah $(2,1 \%)$. Hanya gangguan saraf sudah dikenal luas sebagai penyebab epilepsi, sedangkan yang lain masih kurang diketahui. Hal ini berbeda dengan hasil yang didapat oleh Ann J dkk di Britania Raya tahun 2004 dimana penyebab epilepsi yang terbanyak diketahui responden adalah keturunan (57\%) dan A. Bener dkk di Arab Saudi tahun 1998 yaitu menemukan penyebab epilepsi yang terbanyak diketahui responden adalah penyakit otak $(16,5 \%)^{7,12}$ Ada $15,4 \%$ responden yang tidak tahu mengenai etiologi epilepsi. Walaupun jumlahnya kecil, masih ada masyarakat yang menganggap bahwa epilepsi disebabkan oleh kutukan/ilmu hitam (3,1\%). Hal ini sebanding penelitian Ab Fatah Ab Rahman di Malaysia tahun 2005 dimana sebanyak 5,3\% responden dan penelitian A. Bener dkk di Arab Saudi tahun 1998 yaitu sebanyak 13,8\% responden memilih kutukan/ilmu hitam sebagai penyebab epilepsi. ${ }^{10,12}$

Pada tabel 4.6 menunjukkan persentase gejala epilepsi yang diketahui oleh responden, berurutan dari paling tinggi yaitu kejang (85,6\%), hilang kesadaran (55,7\%), gemetar (53,6\%), hilang ingatan (23,7\%) dan perubahan sikap $(14,4 \%)$. Hanya 3 orang $(3,1 \%)$ yang tidak tahu gejala epilepsi. Penelitian yang dilakukan Ann J dkk juga menempatkan kejang (79\%) sebagai gejala epilepsi yang paling banyak diketahui responden. ${ }^{7}$

Sebanyak 60 orang (66\%) responden beranggapan bahwa saat terjadi serangan, benda keras harus dimasukkan ke mulut penderita. Dari 60 orang tersebut, didapatkan data sumber informasi tersebut, yaitu buku (35\%), televisi $(15 \%)$, orang lain $(68,3 \%)$ dan sumber lain (16,7\%). Hasil ini lebih tinggi dari hasil penelitian oleh Abdelmoneim A dan Fatma S di Kuwait tahun 2008 yang menemukan 11,7\% responden yang beranggapan bahwa benda keras harus dimasukkan ke mulut penderita saat terjadi serangan. ${ }^{11}$ Hal ini menunjukkan masih tingginya pemahaman yang salah tentang cara penanganan saat terjadi serangan epilepsi. Padahal hal ini akan membahayakan penderita epilepsi tersebut.

Penelitian menunjukkan pengetahuan masyarakat mengenai penatalaksanaan 
epilepsi, yaitu 91,4\% responden percaya bahwa epilepsi dapat disembuhkan, hasil ini lebih tinggi dari data yang didapat oleh $\mathrm{Ab}$ Fatah Ab Rahman, dimana hanya 46,3\% responden yang percaya bahwa epilepsi dapat disembuhkan. ${ }^{10}$ Sebanyak 63,4\% responden menganggap obat adalah satusatunya cara mengendalikan epilepsi, hasil ini sebanding dengan hasil penelitian oleh Abdelmoneim A dan Fatma S di Kuwait tahun 2008 yaitu 57,1\% responden menganggap obat adalah satu-satunya cara mengendalikan epilepsi. ${ }^{11}$ Hal ini menunjukkan bahwa sebagian masyarakat sudah paham bahwa epilepsi dapat dikendalikan dengan obat.

\section{SIMPULAN}

Dari hasil penelitian dapat disimpulkan bahwa walaupun sebagian besar masyarakat kelurahan Mahena, Tahuna sudah memiliki tingkat pengetahuan cukup tentang epilepsi, masih banyak juga yang memiliki tingkat pengetahuan kurang tentang epilepsi.

\section{UCAPAN TERIMA KASIH}

Penulis ingin mengucapkan terima kasih kepada dr. Cory Mahama, SpS sebagai dosen penguji 1 dan dr. Herlyani Khosama, SpS sebagai dosen penguji 2 atas kritik dan saran yang membangun selama pelaksanaan penelitian ini, juga kepada semua pihak yang secara langsung maupun tidak langsung membantu penulis dalam proses penelitian ini.

\section{DAFTAR PUSTAKA}

1. Tjahjadi P, Dikot Y, Gunawan D. Gambaran umum mengenai epilepsi. Dalam: Harsono. Kapita selekta neurologi. Ed ke-2. Yogyakarta: Gajah Mada University Press; 2009. 119-33.
2. WHO. Atlas: Epilepsy Care in The World. Geneva:World Health

Organization; 2005 (Diunduh tanggal 21 September 2013).

Tersedia di www.who.int/entity/mental_health/neuro logy/Epilepsy_atlas_r1.pdf

3. Bell G.S, Sander J.W. The epidemiology of epilepsy: the size of the problem. Seizure. 2001;10:306-16.

4. Harsono. Buku ajar neurologi klinis. Yogyakarta: Gajah Mada University Press; 2008. 119-33

5. de Boer H.M, Mula M, Sander J.W. The global burden and stigma of epilepsy. Epilepsy behave. 2007;12(4):540-6.

6. Baker G.A. The psychosocial burden of epilepsy. Epilepsia. 2002;43(Suppl. 6):26-30.

7. Jacoby A, Gorry J, Gamble C, Baker G.A. Public knowledge, private grief: a study of public attitudes to epilepsy in the United Kingdom and implication for stigma. Epilepsia. 2004;45(11):1405-15.

8. Saing J.H. Tingkat pengetahuan, perilaku dan kepatuhan berobat orang tua dari pasien epilepsi anak di Medan. Sari pediatric. 2010: 12(2):103-7

9. Chung K. Knowledge, attitudes, and practices toward epilepsy (KAPE) survey of Chinese and Vietnamese college student in U.S. Berkeley Scientific Journal. 2010;13(2):33-44.

10. Ab Rahman A.F. Awareness and knowledge of epilepsy among student in a Malaysian university. Seizure. 2005;14:593-6.

11. Awad A, Sharkoo F. Public knowledge and attitudes toward epilepsy in Kuwait. Epilepsia. 2008; 49(4):564-72.

12. Bener A, Al-Marzooqi, Ztriha L. Public awareness and attitudes towards epilepsy in the United Arab Emirates. Seizures. 1998;7:219-22. 